\title{
The Implementation of ljarah in Producing the Wakaf Property: Studies in Penang, Malaysia
}

Surita Hartini Mat Hassan, Sakinatul Raadiyah Abdullah, Farahdina Fazial, Che Khadijah Hamid, Salimah Yahaya

To Link this Article: http://dx.doi.org/10.6007/IJARBSS/v11-i1/9007

DOI:10.6007/IJARBSS/v11-i1/9007

Received: 05 November 2020, Revised: 07 December 2020, Accepted: 18 January 2021

Published Online: 27 January 2021

In-Text Citation: (Hassan et al., 2021)

To Cite this Article: Hassan, S. H. M., Abdullah, S. R., Fazial, F., Hamid, C. K., \& Yahaya, S. (2021). The Implementation of Ijarah in Producing the Wakaf Property: Studies in Penang, Malaysia. International Journal of Academic Research in Business and Social Sciencess, 11(1), 849-857.

Copyright: (c) 2021 The Author(s)

Published by Human Resource Management Academic Research Society (www.hrmars.com)

This article is published under the Creative Commons Attribution (CC BY 4.0) license. Anyone may reproduce, distribute, translate and create derivative works of this article (for both commercial and non-commercial purposes), subject to full attribution to the original publication and authors. The full terms of this license may be seen

at: http://creativecommons.org/licences/by/4.0/legalcode

Vol. 11, No. 1, 2021, Pg. 849 - 857

Full Terms \& Conditions of access and use can be found at http://hrmars.com/index.php/pages/detail/publication-ethics 


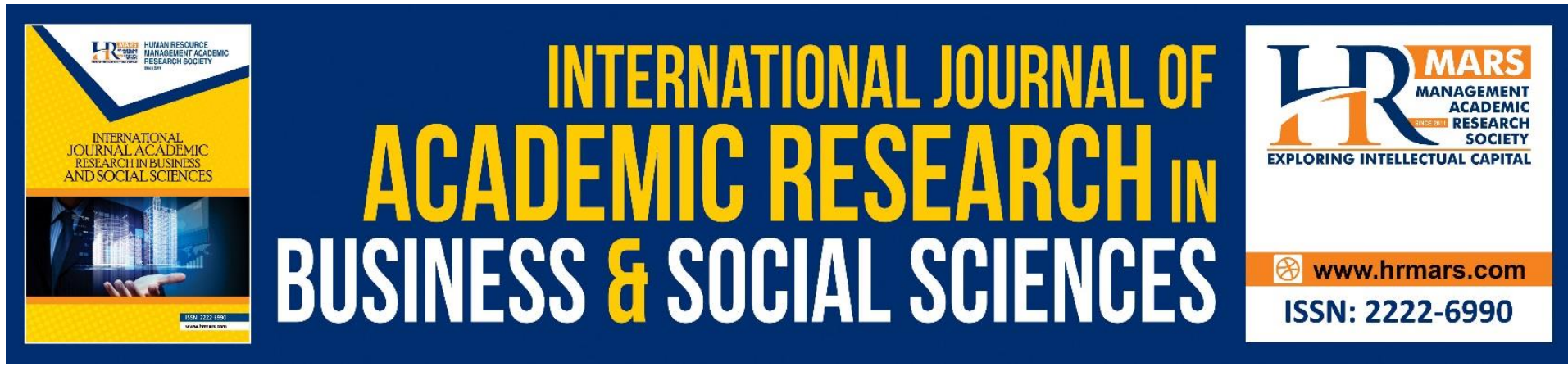

\title{
The Implementation of ljarah in Producing the Wakaf Property: Studies in Penang, Malaysia
}

\author{
Surita Hartini Mat Hassan \\ Universiti Teknologi MARA Cawangan Pahang, Kampus Raub, Pahang, Malaysia. \\ Email: suritahartini@uitm.edu.my \\ Sakinatul Raadiyah Abdullah \\ Universiti Teknologi MARA Cawangan Pahang, Kampus Jengka, Pahang, Malaysia.
}

\author{
Farahdina Fazial \\ Universiti Teknologi MARA Cawangan Kedah, Merbok, Kedah, Malaysia.
}

Che Khadijah Hamid, Salimah Yahaya

Universiti Teknologi MARA Cawangan Terengganu, Kampus Dungun, Terengganu, Malaysia.

\begin{abstract}
The main challenge faced by the Majlis Agama Islam Negeri (MAIN) in their efforts to develop the wakaf lands productively is the lack of funds. To overcome this, MAIN has implemented several halal financing methods, either traditional or contemporary. One of the halal financing methods that MAIN is currently paying attention to is renting or leasing wakaf properties (building and land wakaf) to individuals and even non-government companies or Government Link Company (GLC) to productify these wakaf properties, more commonly known as wakaf distribution methods. Majlis Agama Islam Negeri Pulau Pinang (MAINPP) is one of the MAINs who are rather advanced in developing the wakaf properties productively, using the method of ijarah wakaf. The implementation is proven to successfully productify the wakaf properties in Penang. Based on this phenomena, this research is done to achieve two goals. First, to identify the development project on the wakaf properties in Penang which applied the method of ijarah wakaf. Second, to analyse the effect of the implementation of the method in productifying the wakaf properties. This research involves methods of collecting data from document sources and in-depth interviews with MAINPP wakaf officers. Content analysis is used for the analysis of data. The findings showed that there are several development projects in Penang which applied the ijarah wakaf by the MAINPP, including the Perumahan Wakaf Seetee Aisah in Seberang Jaya and Perumahan Wakaf Khan Mohamed in Georgetown, Penang. The analysis shows that the application of the ijarah wakaf successfully productify the wakaf properties in Penang because the benefits of such development can be taken advantage of.
\end{abstract}

Keywords: Funding, ljarah, Wakaf, Productive, Penang 


\section{Introduction}

Wakaf is one of the socio-economic development mechanisms of Muslims because of its potential to contribute to the growth and social development as well as the nation's economy, if managed well. This has been proven with the success of the implementation of wakaf during the Ottoman (Uthmaniah) period. Throughout this period, wakaf assets are a source of funding for the government in providing access to the community especially for the education sector through the construction of schools and institutions of higher learning; the health sector through the construction of hospitals and the provisions of free treatment; the religious sector through the construction of masjid and surau; as well as infrastructure facilities such as roads, bridges and others using funds raised from the benefit of wakaf (Othman, 2015)

However, in Malaysia to this day there are still many wakaf properties that cannot be developed, especially land. Based on the data collected from JAWHAR, there are about 11, 098 hectares of wakaf land still left without any development (Hamid 2016). This situation results in the non-productive wakaf properties being unable to function properly. This is due to the shortage of funds to develop the existing wakaf assets. This situation has prompted MAIN to obtain a halal source of funding to finance the development projects on wakaf properties. The halal funding implemented by MAIN involves both traditional and contemporary methods (Omar \& Rahman, 2015). One of the traditional methods which garnered the most attention among the mutawalli is the method of ijarah wakaf. The Majlis Agama Islam Pulau Pinang (MAINPP) is among the few active MAINs and advanced in development the wakaf assets using the method of ijarah wakaf.

Therefore, this study was conducted to achieve two goals. First, to identify the wakaf property development project that applied the method of ijarah wakaf in Penang. Second, to examine the impact of the implementation of the development. Thus, the discussion in the paper begins with the highlight of the previous studies, followed by discussion on the application of ijarah wakaf in the development of wakaf land in Penang, the impact of its implementation and summed in with a conclusion.

\section{Research Method}

This research involves qualitative data which is obtained from primary and secondary sources. The primary source is acquired from in-depth interviews with an informant which is one of the MAINPP officers who are involved directly in managing, administering and developing the wakaf properties and lands in Penang. In this paper, the officer is coded as PPW 01 to maintain the confidentiality of the data and information provided. Secondary sources are obtained through research on document sources such as books, journals, magazines and so on. These data were then analyzed by qualitative content analysis.

\section{Findings and Discussion}

\section{The Implementation of ljarah Wakaf in Penang}

Generally, ijarah or better known by the term rent refers to a contract to obtain certain services (benefits) that can be paid and legalized for certain goods. The contract in question is an agreement to transfer ownership of services (benefits). This ijarah contract is authorized and in accordance with the syara' (Al-Bakri, 2014: 185). In the context of wakaf, ijarah refers to the halal financing method applied by mutawalli to obtain the proceeds from the benefit 
of wakaf property. At the same time, the implementation can productify as well as contribute benefits continuously. The beneficial wakaf assets will be rented or leased to those who need and able to expand the properties (Hassan, et al., 2020). For this research, it is focused on two development projects in Penang which applied the ijarah method which are the Seetee Aisah wakaf land development and the Khan Mohamed wakaf land. This is due to the fact that these two projects are among the successful projects to productify the wakaf lands which involves large amounts of funds.

\section{The Development of the Seetee Aisah Wakaf Land}

9.86 acres (39902.04 square meters) of land (Omar \& Rahman, 2015: 113), was originally a paddy field ${ }^{1}$. The Seetee Aisah wakaf land in Seberang Jaya, Penang, is located nearby several of the largest supermarkets, such as Tesco Extra, Sunway Carnival, Billion and Giant. This situation gave the MAINPP an idea to develop the wakaf land as a housing estate because of its strategic location and able to fulfill the needs of the community (PPW 01, 2016).

This wakaf land has been successfully built for housing in a musyarakah collaboration with the Project which started on February 25, 2010 costing RM 15 million. The project includes the construction of nine three-storey shop units and 76 two-storey terraced house units which was completed in February 2013. The sale of the house has been using the leased hold method for 99 years. The method of implementation of the Seetee Aisah wakaf housing project is shown in Figure 1. Figure 1 shows an overview of the Setee Aisah wakaf housing project implementation ${ }^{2}$. Based on the observation, the construction of the Setee Aisah wakaf housing involves a musyarakah funding method that applies two financial mechanisms, which are ijarah and tawarruq. This method has successfully productify the wakaf land as the benefits can be used indefinitely by the homeowner for 99 years. However, in order to maintain the productivity of the building, MAINPP needs to devise a strategy so that the next generation can enjoy the benefits not only for the 99 years but for more than that, for example 198 years. The next generation of heirs or other beneficiaries must also understand and abide by the rules and agreements as set out in the event of any transfer as well as misunderstanding of the rights and ownership of the wakaf property.

\footnotetext{
${ }^{1}$ Declared for wakaf by Seetee Aisah Binti Haji Mahmood on 30 September 1901 (Omar \& Rahman, 2015: 113)

2 1. Began with sealing of the agreement between MAINPP and UDA Land to develop a housing estate on the Setee Aisah wakaf land; 2. The UDA Land Company appointed the engineering company, Seri Gemilang Sdn. Bhd as the developer contractor to develop the project; 3. Seri Gemilang Engineering Company Sdn. Bhd has built 76 units of two-storey terraced houses and nine three-storey shop units; 4 . The sale of the houses to Muslim homeowners (beneficiaries) as temporary owners of leased terraced houses for 99 years for as low as RM 281,800 to RM 439, 600 units; 5 . Home buyers get the fundings through Bank Muamalat Sdn Bhd on the terms of tawarruq; 6 . The fundings are submitted to UDA Land as capital for the construction of the project; 7. Nine store units belong to the MAINPP as per the agreement; 8 . The building is leased to any dealers wanting to do business in the area. The rental payment is submitted to MAINPP; 9 . 30 percent of the proceeds from the sale of the home benefits are given to MAINPP, while the rest is given to UDA Land.
} 


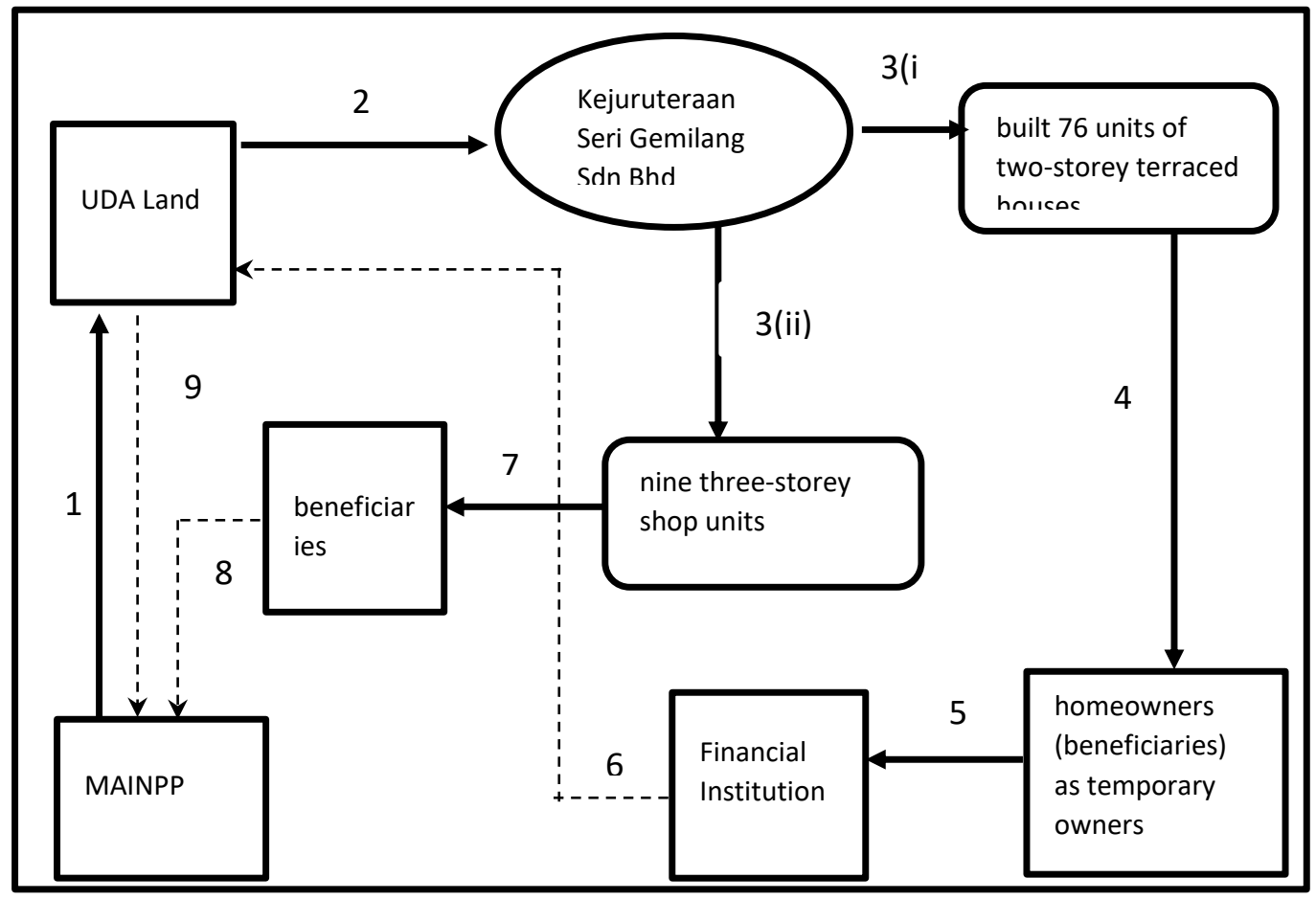

Figure 1: Method of Implementing Housing Development of Seetee Aisah Housing Source: Researchers' summary based on description of PPW 01 (2016).

The development benefited MAINPP through rentals of nine stores totaling RM56,000 a month. MAINPP also received a 30 percent musyarakah profit of RM600,000. This amount exceeds the amount allotted to be distributed to the mauquf 'alaih as intended by the wakaf appellant ${ }^{3}$. The surplus is used for the purpose of raising funds, whether to invest or buy another wakaf building. With the success of this development, MAINPP has approved a second phase development project on this landfill for RM200 million with UDA Land. Besides the continuation of benefits for the mauquf 'alaih and retaining the 'ayn of wakaf assets, it can also add new wakaf properties and further enhance its sustainability. In contrast, with the conditions before this housing development took place, the Seetee Aisah wakaf land was filled with erected squatter houses that did not bring any benefit to MAINPP.

Besides that, this development has been able to provide economic, geopolitical and social impact to the Muslim community following the phase 1 of development of Seetee Aisah wakaf. From the economic point of view, the development of the Seetee Aisah wakaf provides commercial lot rentals of about RM56,000.00 a month (approximately RM672,000 a year), provides employment opportunities for those involved in commercial lot business, and service sector in the security management of the Seetee Aisah neighbourhood. What is

\footnotetext{
${ }^{3}$ There are four conditions set by the appellant to the trustee 1 . Hold a one-day feast during the month of Ramadan and a fee of RM 3 for the attending congregation; 2. Pay and supply one can of petrol to the mosque in the vicinity of Permatang Pauh area during Ramadan each year
}

; 3. Send money every year to Makkah and so on for the purposes of umrah; 4 . The proceeds will be used for the repairs of a masjid in the Permatang Pauh area or sent to Makkah for waqf or other charitable causes, half of which will be donated for the benefit of the heirs (Saedah Nordin and her descendants) for their own benefit (Omar \& Rahman, 2015: 114-115) 
important is to make this Seetee Aisah wakaf property belongs to MAINPP as the sole trustee of the wakaf in Penang as the mutawalli.

The development of Setee Aisah also managed to uphold the Muslim community in Penang and enabling to get a place of residence in the city center where the cost of housing is very high. With this housing, they are are able to provide the Muslim community settlements, where all the housing lots are leased to the Muslim community. This has helped to reduce the outflow of the Muslim community from the city. The development of Seetee Aisah has also created a surau which is a staple in the gathering of Seetee Aisah community members, not only in the context of worship but also in the context of social relations involving marriage and other social activities. This has transformed the earlier passive wakaf property into a more economic, social and geopolitical activity of the Muslim community. The successful implementation of this development has led to the second phase of the development of the Setee Aisah wakaf which is going to be a bigger project, as well as the expansion of the Setee Aisah wakaf as there are still undeveloped areas. It is hoped that the development of this second phase will have a greater impact than the development of phase 1, especially in the spiritual sense, besides economic, political and social aspects.

\section{The Development of the Khan Muhammad Wakaf Land}

The Khan Muhammad's wakaf apartment, Georgetown, Penang also applied the concept of a musyarakah involving MAINPP's joint venture with the JKP Sdn Bhd (Dana Wakaf MAINPP, 2016). The development done at the Pangsapuri Wakaf Khan Mohamed is a development of a modest cost apartment block. The wakaf apartment has four floors with a total occupancy of 32 units and each unit occupies 73.51 square meters. Until now, MAINPP and JKP have issued three leases per unit of which each lease has a term of 33 years for each of the units of the wakaf apartments. The lease price per dwelling unit is RM $112700.00++$ (PPW 01, 2016). This method of implementation is shown in Figure 2. Through the joint venture agreement signed by the JKP and MAINPP, the residential units of the Wakaf Apartments have been agreed to be distributed in a 24-unit ratio to the JKP whereas another eight-unit to MAINPP. Seven MAINPP residential units are rented at RM500 per month and the total monthly income for Wakaf Khan Mohamed is RM4000 per month (PPW 01, 2016).

Figure 2 shows the method of implementation of Khan Mohamed's wakaf land development between MAINPP and JKP ${ }^{4}$. According to the research, the application of the musyarakah method in the development of Khan Mohammed's ${ }^{5}$ wakaf land has succeeded in productify

\footnotetext{
${ }^{4} 1$. The sealing of agreement between MAINPP and JKP to develop the wakaf land of Khan Mohamed; 2 . The JKP builds medium-cost apartments consisting of 32 residential units; 3 . This residential unit is divided into two 24- units for the JKP and 8 units for the MAINPP; 4. The JKP leases 24 residential units provided to home buyers (leaseholders) for the low price of RM $112700.00++$ per unit; 5 . Eight residential units submitted to MAINPP are provided to the beneficiary (tenant) for rent at a rate of RM500 per month; 6 . Lease payments are the property of MAINPP, which to be used in the MAINPP's wakaf fund for capital maintenance and other wakaf land development; 7. The leaser paid the lease money to the developers which is JKP; 8. JKP handed over the payment of Khan Mohamed wakaf land lease to MAINPP for the period of 33 years. To date, MAINPP and JKP have issued three leases for a period of 33 years, making the lease term 99 years.

${ }^{5}$ Khan Mohamed's wakaf land is a special wakaf located in Lot 1525, HS (D) 359, Daerah Timur Laut, Pulau Pinang with a total area of 1638.73 square meters located at No. 257, Jalan Perak, 10150, Pulau Pinang. This land was leased by Khan Mohamed, also known as Khan Rajabee in 1803 . He had expressed his intention to
} 
the wakaf land as it should be. If examined prior to the construction of this modest cost apartment, the Wakaf Khan Mohamed site was a residential rental site for five families with a monthly rent of RM11 only for the MAINPP. In addition, the site of this wakaf also houses squatter housings. The success of this development has benefited more Muslims than ever, where before this, only a handful of people have benefited from it.

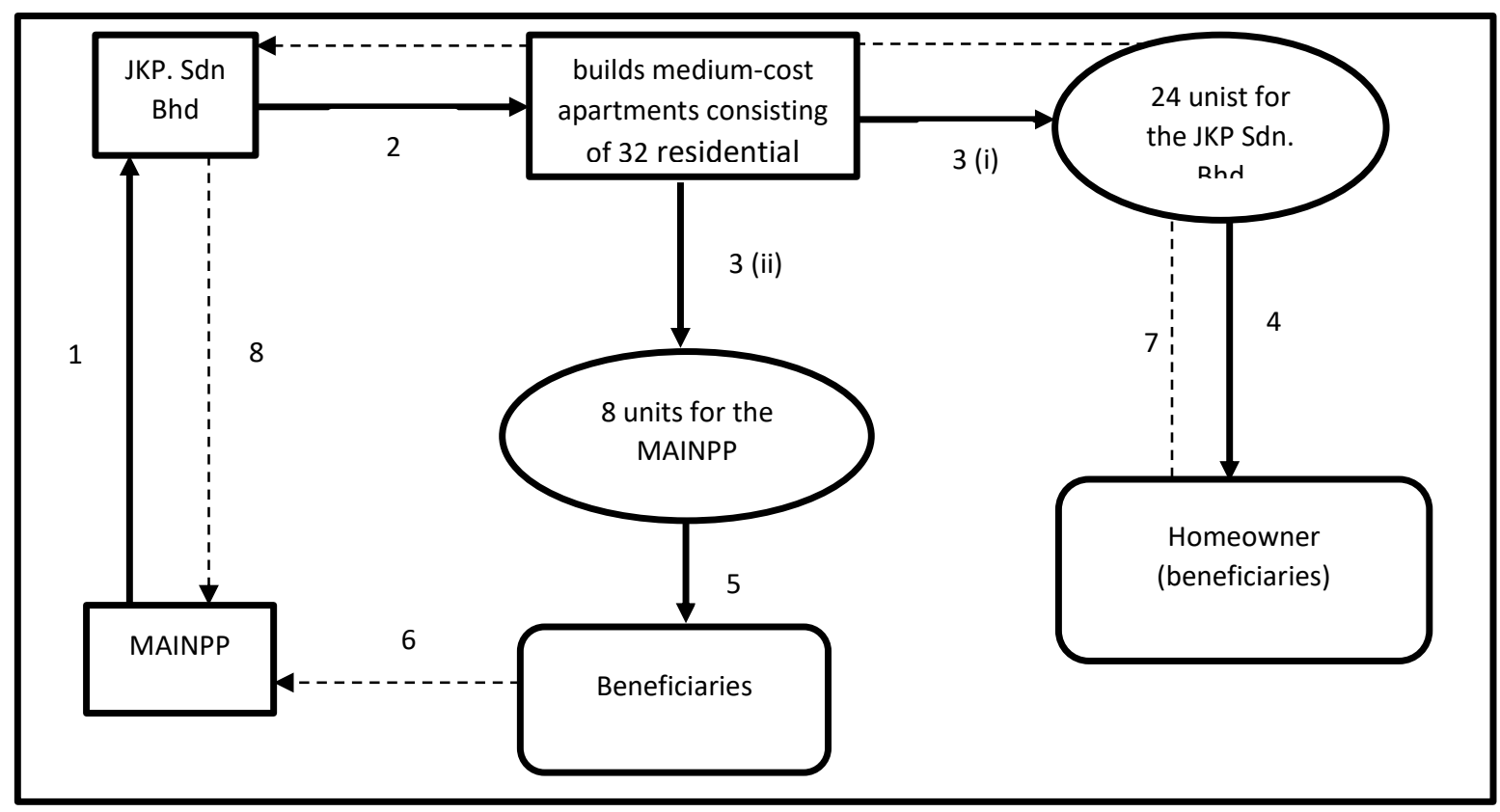

\section{Rajah 2: Method of the Implementing Housing Development of} Tanah Wakaf Khan Mohamed Sources: Researchers' summary based on description of PPW 01 (2016)

In addition, MAINPP also benefited from a rent of eight residential units totaling RM4000 per month and lease payments from the JKP. The wakaf land has been successfully productified as intended by the owner of the wakaf. However, comparing between these two developments, the Seetee Aisah wakaf land is seen to have more potential for further developments as there is still a lot of undeveloped land compared to the Khan Mohamed wakaf lands as it has been utilized completely for the purpose of the construction of the apartments. However the proceeds or benefits derived from the rental proceeds can be used for the purpose of adding new wakaf assets by purchasing other properties whether land or buildings for rent or lease. This situation allows the wakaf property to be maintained and its benefits continued.

The impact of Khan Mohamed's wakaf development has been somewhat smaller than that of Seetee Aisah's wakaf development in the development of musyarakah financing, but it is still possible to expand and extend the benefits of wakaf property to the mawkuf alaih. From the 
economic point of view, it is seen that the revenue from the wakaf has increased from RM55.00 per month to RM4000.00 per month. The entirety of this housing will be a wakaf land managed by the MAINPP as the mutawalli upon the expiry of the JKP lease. Obviously it will increase the property and be able to operate the wakaf property by increasing the distribution of benefits due to the increased revenue of the wakaf. In addition, it has been able to provide a settlement to the Muslim community with a fair price compared to the market price. This situation has led to the Muslim community being pushed out of the city center. In the end, of course, this placement has created a social connection from the settlers to the good in both worship and social life.

\section{Conclusion}

In conclusion, the development on the wakaf land is a very important matter at this time because it has the potential to contribute to the well-being of Muslims. The construction of the residential units on the Seetee Aisah and Khan Mohamed wakaf lands has shown that a wakaf property can meet the needs of the community to obtain home protection, even temporarily. The implementation of the development of the wakaf lands of Seetee Aisah and Khan Mohamed in Penang has successfully preserved the 'ayn (land) of the wakaf property and provided continuous benefits. In addition it can also expand the wakaf property.

At the same time, it provides employment and business opportunities for the Muslim community to conduct business. This allows the property and benefits to be preserved. The integration of the methods of musyarakah in the development of wakaf land can produce the land not only in the form of housing, but also in other forms of economic development, especially in the economic, political and social context that can sustain the Muslim community living in the city center. The efforts done by the MAINPP should be used as a guidance by the other Majlis Agama Islam Negeri (MAIN) throughout the country in order to empower the development of the wakaf land which are abandoned without any developments.

\section{References}

Al-Bakri, Z. M. (2014). Al-Fiqh al-Manhaji: Muamalat dan kewangan Islam dalam figh alsyafi'i. Selangor: Darul Syakir Enterprise.

Bahari, Z. (2012). Pemerkasaan instrumen wakaf dalam pembangunan ekonomi. Siri Kertas ISDEV, No. 38. Pulau Pinang: Pusat Kajian Pengurusan Pembangunan Islam (ISDEV), USM.

Bahari, Z. (2013). Pembiayaan pembangunan pengajian tinggi: Kes pembangunan wakaf kompleks ISDEV, Universiti Sains Malaysia. Kertas kerja yang dibentangkan di Seminar Serantau Institusi Pengajian Tinggi Islam (SeiPTI2013) di Brunei pada 4-5 Disember bertempat di Bandar Sri Begawan, Brunei.

Bahari, Z., \& Rahman, F. A. (2012). Modes and risk of financing for waqf development: The case of Seetee Aisyah waqf in Penang, Malaysia. Siri Kertas ISDEV, No. 37. Pulau Pinang: Pusat Kajian Pengurusan Pembangunan Islam (ISDEV), USM.

Chandra, H., \& Rahman, A. A. (2010). Waqf investment: A case study of Dompet Dhuafa Republika, Indonesia. Shariah Journal, Vol. 18, No. 1, hlm. 163-190.

Hamid, S. S. (2016). 11,091. 82 hektar tanah wakaf. Di akses daripada, http://www.hmetro.com.my/node/111064\#sthash.eBuiCEHO.dpuf pada 29 Januari 2016. 
Hassan, S. H. M., Bahari, Z., Aziz, A. H. A., \& Doktoralina, C. M. (2020). Sustainable Development of Endowment (Waqf) Properties. International Journal of Innovation, Creativity and Change, 13(4), 1135-1150.

Rani, M. A., Ismail, C. Z., \& Bhari, A. (2015). Pengurusan ljarah Wakaf: Pemangkin transformasi pembangunan ekonomi di negeri Selangor. Proceedings of the International Conference on Waqf 2015 (ICW2015). Kuala Terengganu, Terengganu: Universiti Sultan Zainal Abidin (UNISZA).

Omar, A. A., Bakar, A. A., Shuib, M. S., \& Jusoh, M. K. A. (2014). Penggunaan kaedah B.O.T dalam usaha membangunkan tanah wakaf Majoodsaw Pulau Pinang. Kerta kerja yang dibentangkan di Muktamar Waqf Iqlimi 2014, The Asean Endowment Seminar 2014, pada 29 April 2014, bertempat di Universiti Sains Islam Malaysia, Nilai, Negeri Sembilan. Diakses dari (UUM)1file://C:/Users/User/Downloads/PENGGUNAAN\%20KAEDAH\%20Bot\%20dal am\%20pembangunan\%20harta\%20wakaf.pdf

Omar, H. H., \& Rahman, A. A. (2015). Pembiayaan pembangunan harta wakaf menggunakan sukuk. Kuala Lumpur: Universiti Malaya.

Omar, H. H., \& Rahman, A. A. (2013). Aplikasi sukuk dalam usaha melestarikan aset wakaf: Pengalaman pemegang amanah wakaf terpilih. Jurnal Syariah, vol. 21, No. 2, hlm. 89116.

Othman, R. (2015), Wakaf Tunai: Sejarah, Amalan dan Cabaran Masa Kini. Kuala Lumpur, Dewan Bahasa dan Pustaka.

Rachmad, D. (2014). Strategi pengembangan investasi harta wakaf: Suatu kerangka konseptual. Inovbiz, Vol. 2, No. 1, hlm. 69-82.

Saniff, S. M., \& Hasan, W. N. W. (2009). Isu dan cabaran dalam pasca PTW: Kajian kes Pangsapuri Wakaf Khan Mohamed di Jalan Perak, Pulau Pinang. Kertas kerja yang dibentangkan di Worskhop Antarabangsa II, Universitas Muhammadiyah Sumatera Utara (UMSU), Medan, Indonesia, pada 4-10 Mei 2009. 